\title{
Expression of metallothionein in liver and kidney of freshwater fish Cyprinus carpio var. communis (Linn) exposed to arsenic trioxide
}

\author{
K. Kovendan ${ }^{1,{ }^{*} \text {, S. Vincent }}{ }^{2}$, S. Janarthanan ${ }^{3}$ and M. Saravanan ${ }^{4}$ \\ ${ }^{1}$ Division of Entomology, Department of Zoology, School of Life Sciences, \\ Bharathiar University, Coimbatore-641 046, Tamil Nadu, India. \\ ${ }^{2} \mathrm{PG} \&$ Research Department of Advanced Zoology and Biotechnology, \\ Loyola College, Chennai-600 034, Tamil Nadu, India. \\ \& Tamil Nadu State Council for Science and Technology, Chennai-600 025, Tamil Nadu, \\ India \\ ${ }^{3}$ Department of Zoology, University of Madras, Maraimalai Campus, Guindy, \\ Chennai-600 025, Tamil Nadu, India. \\ ${ }^{4}$ Unit of Toxicology, Department of Zoology, School of Life Sciences, \\ Bharathiar University, Coimbatore-641 046, Tamil Nadu, India.
}

\begin{abstract}
In the present study, the toxic effects of arsenic trioxide $\left(\mathrm{As}_{2} \mathrm{O}_{3}\right)$ to freshwater fish $C$. carpio were estimated at different median lethal concentration levels and its influences on the expression of metallothionein (MT) activity in liver and kidney were also observed. During this study, LC $_{50}$ values were found to be 25.7, 27.4, 29.5, and $32 \mathrm{ppm}$ for the period of 24, 48, 72, and $96 \mathrm{hrs}$ respectively and $\mathrm{LC}_{16}$ and $\mathrm{LC}_{84}$ values of $\mathrm{As}_{2} \mathrm{O}_{3}$ also measured. The MT activity was estimated in liver and kidney of fish treated with different concentrations of $\mathrm{As}_{2} \mathrm{O}_{3}(5,15$, and $20 \mathrm{ppm})$ at different time intervals $(48,96$, and $144 \mathrm{~h}$ ) by using SDS-PAGE technique. From the results, $5 \mathrm{KD}$ and $6 \mathrm{KD}$ polypeptides were known to be metallothionein in liver and kidney respectively when the fishes were treated with different concentrations of $A s_{2} \mathrm{O}_{3}$. In the present investigation, $\mathrm{As}_{2} \mathrm{O}_{3}$ induced significant expression on MT activity and it can be useful biomarker in environmental biomonitoring of arsenic contamination.
\end{abstract}

Keywords: Cyprinus carpio, Arsenic trioxide, SDS - PAGE and Metallothionein.

\section{INTRODUCTION}

In nature, the occurrence of arsenic and its metabolites are higher in the aquatic environment which may be washed out of arsenic bearing rocks (Edmonds and Francesconi, 1993). From the anthropogenic activities such as treatment of agricultural land with arsenical pesticides, treating of wood using chromated copper arsenate, burning of coal and the operations of gold-mining, industries like glass, pharmacy, pigment, dyes and also used as a preservative of animal hides are responsible to increased level of arsenic in soil, minerals, surface and groundwater in the environment (Pacyna et al., 1995; Antman, 2001; Rodriguez et al., 2003; Palaniappan and Vijayasundaram, 2008; Saxena, et al., 2009). It makes a serious problem to aquatic ecosystem and organisms and alarming issue throughout the world (Goering et al., 1999). In recent years, contamination of aquatic environment by arsenicals and their impacts on the aquatic organisms has now emerged as a serious environmental problem (Allen et al., 2004). In aquatic systems, inorganic arsenic can occur in both $\mathrm{As}^{3+}$ and $\mathrm{As}^{5+}$ oxidation states. The level of $\mathrm{As}^{3+}$ to $\mathrm{As}^{5+}$ depends on the influences of $\mathrm{pH}$, metal sulfide and sulfide ion concentrations, iron concentration, temperature, salinity, and the distribution of the biota in an aquatic ecosystem (Wakao et al., 1988).

The previous literatures have been clearly reported that the higher concentrations of arsenic was observed in many countries of the world especially in Asian continent (India, Banladesh, China, Chile, Mangolia and Taiwan, Chile, Thailand, Japan), in Europe (Hungery) and some of the places in Mexico, Argentina, America and Canada (Vahter, 1994; Chakraborty et al., 2003; Chaudhuri et al., 2008). For instance, groundwater arsenic contamination has assumed an alarming proportion in large part of West 
Bengal, India and more than 6 million people are exposed to arsenic through drinking water which is maximum contamination limit stipulated by World Health Organization (Chaudhuri et al., 2008) and considered as the worst environmental disaster. Hence, it has been earmarked as the most important arsenic calamity in the world (Das et al., 1994).

According to previous reports, arsenic is a most important environmental toxicant worldwide (ATSDR, 2002; Ratnaike, 2006). It causes a wide range of pathological conditions and chronic diseases in humans (IARC, 1980, 1987). The arsenic contamination in drinking water is a major problem in many parts of the world where the people intake of arsenic contaminated water and food, particularly skin, nervous system, gastrointestinal system, various forms of cancer, melanosis, leuco-melanosis, keratosis, hyperkeratosis, dorsum, non petting oedema, gangrene, skin cancer and skin lesions in sole and palm (IARC, 1987; NRC, 1999; Karim, 2000; Bernstam and Nriagu, 2000; Nordstrom, 2002; Jin et al., 2004; ATSDR, 2006; Palaniappan and Vijayasundaram, 2009). Allen et al., (2004) reported that toxicity of arsenicals in animals depends on species, sex, age, exposure dose, duration of exposure, organic or inorganic forms, valence state, etc., In freshwater fish, Arsenic can be present in two different oxidation states, as arseno-sugars and arseno-lipids, these two differ in their toxicity which is supposed to be responsible for the pathophysiology of arsenic (Bears et al., 2006). In addition, the semimetal arsenic at high concentration is lethal to many organisms including fishes and also low concentration produces several diseases under long term exposure (Hughs, 2002).

Among the various arsenic compounds, arsenic trioxide $\left(\mathrm{As}_{2} \mathrm{O}_{3}\right)$ is a trivalent inorganic compound of arsenic and is mostly used in synthesis of various inorganic and organic compounds for many purpose (Lavanya et al., 2011) such as chemotherapeutic agent for the treatment of hematological malignancies (List, 2002). $\mathrm{As}_{2} \mathrm{O}_{3}$ is the dominant almost $50 \%$ of the total arsenic level in most of the arsenic contaminated area in India (Chatterjee et al., 1993). In the aquatic environment, fish appear to be valuable bioindicator of arsenic toxicity as they are continuously exposed to arsenic through gills respiration and intake of arsenic contaminated food get accumulated in various tissues (Gernhofer et al., 2001; Bears et al., 2006; Ghosh et al., 2007). After entering, it transformed into methylated form, arsenosugars and arsenolipids forms which combinations in fish tissue leads to pathophysiology (Phillips, 1990; Wrobel et al., 2002; Bears et al., 2006). Basically, fish is a common source of protein, contains greater quantity of protein content than any other living organisms contributing roughly about $75 \%$ by weight of the fish. Proteins play a major part in all biological systems with a wide variety of structural and functional roles.

Arsenic compounds show toxicity in many organs of body such as kidney, liver, lung, gastro intestinal tract, gallbladder and respiratory tract (Pedlar et al., 2002; Roy and Bhattacharya, 2005; Vahter, 2004). Among these, liver and kidneys are vital organs in vertebrates which perform detoxification mechanism, homeostatic functions, protein synthesis and excretion of nitrogenous waste respectively. In deed, analysis of biochemical parameters in aquatic organisms is used to revealing of status of stress, mode of action of toxicants in monitoring of aquatic environment (Vutukuru, 2003). The ecotoxicological markers such as various peptides and proteins could be very useful tool for rapid and easy assessment of the heavy metal toxicity. Metallothionein (MT) is a ubiquitous metalloprotein found in bacteria, invertebrates and mammals (Kagi and Vallee, 1960; Robinson et al., 1990; Sturzenbaum et al., 1998). It belongs to a group of intracellular, high molecular and cysteine-rich proteins with molecular weight from 6 to $10 \mathrm{KD}$ and used as a potentially good biomarker of metal contamination in fish (Kagi and Schaffer, 1988; Kizek et al., 2001; Trnkova et al., 2002). In addition, induction of MTs (metal transporters, and antioxidative proteins) represents a major means of metal detoxification in the body to maintain trace elements, metal homeostasis and body protection from the damage by metal overload (Stillman et al., 1992; Kang, 2006; Krezel and Maret, 2008; Maret, 2008; He and $\mathrm{Ma}, 2009)$. Inorganic As induces MT expression and $\mathrm{As}_{2} \mathrm{O}_{3}$ appears to be as potent an MT inducer (Albores et al., 1992).

Even though the toxicity of arsenic trioxide in aquatic system has enormously documented, reports on freshwater fish are still scarce (Ghosh et al., 2006). Hence, in the present study we aimed to assess the effects of $\mathrm{As}_{2} \mathrm{O}_{3}$ on C. carpio, a commonly inhabits of freshwater bodies. It is widely tolerable to environmental factors and a common food for many people in Asian continent including India and in order to understand the mode of action, stress response, metallothionein expression in liver and kidney. 


\section{MATERIAL AND METHODS}

Test chemicals: The analytical grade arsenic trioxide $\left(\mathrm{As}_{2} \mathrm{O}_{3}\right.$; CAS No.: 1327-53-3) was purchased from Labo Chemie, Mumbai, India and used without further purification for the experiment.

Test animal and experimental design: Fingerlings of C. carpio (length $8.2 \pm 0.4 \mathrm{~cm}$ and weight $10.5 \pm 1$ g) were procured from the Bharath Fish Seed Farm, Budhur, Tamil Nadu, India and brought to the laboratory. They were acclimatized for 25 days in a large cement tank (1000 L capacity) under laboratory conditions before they were exposed to arsenic treatment. During the acclimatization, the fish were fed ad libitum with rice bran and groundnut oil cake and the water was changed daily to discard the excretory wastes and feeding was withheld $24 \mathrm{~h}$ before the commencement of the experiment. In the present study tap water free from chlorine was used and the water had the following physico-chemical characteristics (APHA, 1998); temperature $26 \pm 1^{\circ} \mathrm{C}$, $\mathrm{pH} 7 \pm 0.2$, salinity $0.30 \pm 0.1 \%$, dissolved oxygen $7.0 \pm 0.02 \mathrm{mg} \mathrm{l}^{-1}$, total hardness $17 \pm 0.5 \mathrm{mg} \mathrm{l}^{-1}$, alkalinity $34.0 \pm 5 \mathrm{mg} \mathrm{l}^{-1}$, calcium $4 \pm 0.51 \mathrm{mg} \mathrm{I}^{-1}$ and magnesium $2 \pm 0.2 \mathrm{mg} \mathrm{l}^{-1}$. Before the start of the experiment suitable number of fish was transferred into two glass aquaria which were continuously aerated.

Acute toxicity test: $\mathrm{As}_{2} \mathrm{O}_{3}$ stock solution was prepared using distilled water and desired degrees of concentrations were prepared. Based on the progressive big sections with intervals on a logarithmic scale, concentrations were fixed after conducting the range finding test (APHA, 1980). Feeding of fish was stopped $24 \mathrm{~h}$ prior to the commencement of the experiment with a view to avoid any possible change in situ in the toxicity of $\mathrm{As}_{2} \mathrm{O}_{3}$. After the addition of toxicant into the test tank with 5 liters of water 4 fishes, mortality was recorded once in two hours of a day. Fish showing no respiratory movement and response to tactile stimuli were considered as dead and removed immediately. Percent mortality was calculated and the values were transformed in the probit scale. Probit analysis was calculated as per Finney (1942) method. Probit logarithmic transformations of concentration were made. Slope function (S) and Confidential limits (upper and lower) of the regression line Chi-square test were calculated as follows:

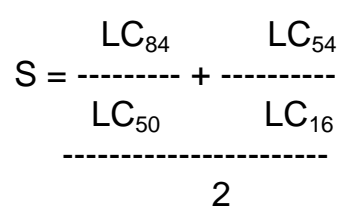

$$
f=\frac{\text { Antilog } 2.77 \log S}{\sqrt{ } N}=S 2.77 \sqrt{ } N
$$

Where $\mathrm{N}$ is the number of fishes tested whose expected effects between $16 \%$ and $84 \%$ mortality.

$$
\begin{aligned}
& \text { Upper confidence limit }=\mathrm{LC}_{50} \mathrm{Xf} \\
& \text { Lower confidence limit }=\stackrel{--C_{50}}{\mathrm{~F}}
\end{aligned}
$$

Based on the acute toxicity test, four sublethal concentrations $5 \mathrm{ppm}, 10 \mathrm{ppm}, 15 \mathrm{ppm}$, and $20 \mathrm{ppm}$ for the $\mathrm{As}_{2} \mathrm{O}_{3}$ were derived and were used as the experimental concentrations. At the end of the experimental periods such as 2, 4 and 6 days, the fish organs were dissected and kept frozen at - $40{ }^{\circ} \mathrm{C}$ until used.

SDS-PAGE Studies: The protocol of Laemmli (1970) was followed with minor modification.

\section{RESULTS}

Median lethal concentration: In the present study, the 24, 48, 72, and 96-h LC ${ }_{16}, 50$, and 84 values of $\mathrm{As}_{2} \mathrm{O}_{3}$ to $C$. carpio was estimated and presented in Table. 1.

\section{Gel Electrophoresis: MT expression in liver and kidney}

Liver: The metallothionein expression in liver of $C$. carpio exposed to the metal $\mathrm{As}_{2} \mathrm{O}_{3}$ at various concentrations (5 ppm, 15 ppm, and 20 ppm) under different time intervals (48 h, $96 \mathrm{~h}$, and $144 \mathrm{~h}$ ) was shown in figure 1. During the study period, electrophorogram showed the separation of polypeptides ranging $120 \mathrm{KD}-5 \mathrm{KD}$. Among various polypeptides there were 5 regions in the electrophorogram where the polypeptides were more intensely stained they were the $120 \mathrm{KD}, 80 \mathrm{KD}, 30$ $\mathrm{KD}$ (including three polypeptides, within this region), $12 \mathrm{KD}$, and $5 \mathrm{KD}$ polypeptides. The control electrophorogram was not presented here, but were run to identify the presence of MT when the related samples were compared to control. The lower most and molecular weight of the polypeptide (5 KD) was 
not observed in the control. Thus, the $5 \mathrm{KD}$ polypeptide was known to be MT which was specifically expressed in the liver samples when the fishes were treated with the arsenic metal. In present observation, except a few lanes not much significant variation was observed among various concentrations of metal treatments as well as different days.

Kidney: The expression of MT activity in kidney of common carp exposed to different concentrations (5 ppm, $15 \mathrm{ppm}$, and $20 \mathrm{ppm}$ ) of arsenic at various time intervals (48 h, $96 \mathrm{~h}$, and $144 \mathrm{~h}$ ) and their SDS-PAGE was presented in figure 2. The results showed the separation of various polypeptides ranging 200 KD-6 $\mathrm{KD}$. There were 4 major regions in the gel where the polypeptides were much more intensely started. They were classified as $200 \mathrm{KD}$ (only one major fraction of polypeptide), $80 \mathrm{KD}$ polypeptide (three fractions were deserved), $30 \mathrm{KD}$ polypeptides (only two polypeptides fractions were deserved) and a $6 \mathrm{KD}$ polypeptide. In addition to this major polypeptide, numerous minor polypeptides were found in the electrophoresis gel (Fig. 2). As there was constant in the gel lanes for loading control, it was not shown along with the treated lanes, the comparison of protein profiles among control and various treatments showed expression at a $6 \mathrm{KD}$ polypeptide in variably in all the treatments which was absent in the control. Thus it was presumed that this $6 \mathrm{KD}$ polypeptide as the MT . Like the liver electrophorogram, the kidney also showed not much significant variations among various concentrations of metal treatments and different time intervals.

Table 1 Acute toxicity test in tolerance of common carp $C$. carpio exposed to different concentrations of arsenic trioxide (ppm)

\begin{tabular}{|l|l|l|l|l|l|l|}
\hline Period of Exposure (Hours) & LC $_{16}$ & LC $_{50}$ & LC $_{84}$ & Slope & \multicolumn{2}{|l|}{ Confidence limit } \\
& & & & & \multicolumn{2}{|c|}{ Upper Lower } \\
\hline 24 & 8.064 & 25.2 & 42.336 & 2.402 & 33.01 & 6.15 \\
\hline 48 & 8.864 & 27.4 & 46.550 & 2.395 & 35.89 & 6.76 \\
\hline 72 & 9.44 & 29.5 & 49.560 & 2.402 & 38.64 & 7.206 \\
\hline 96 & 10.24 & 32.0 & 53.76 & 2.402 & 41.92 & 7.81 \\
\hline
\end{tabular}

\section{Common Carp Liver}

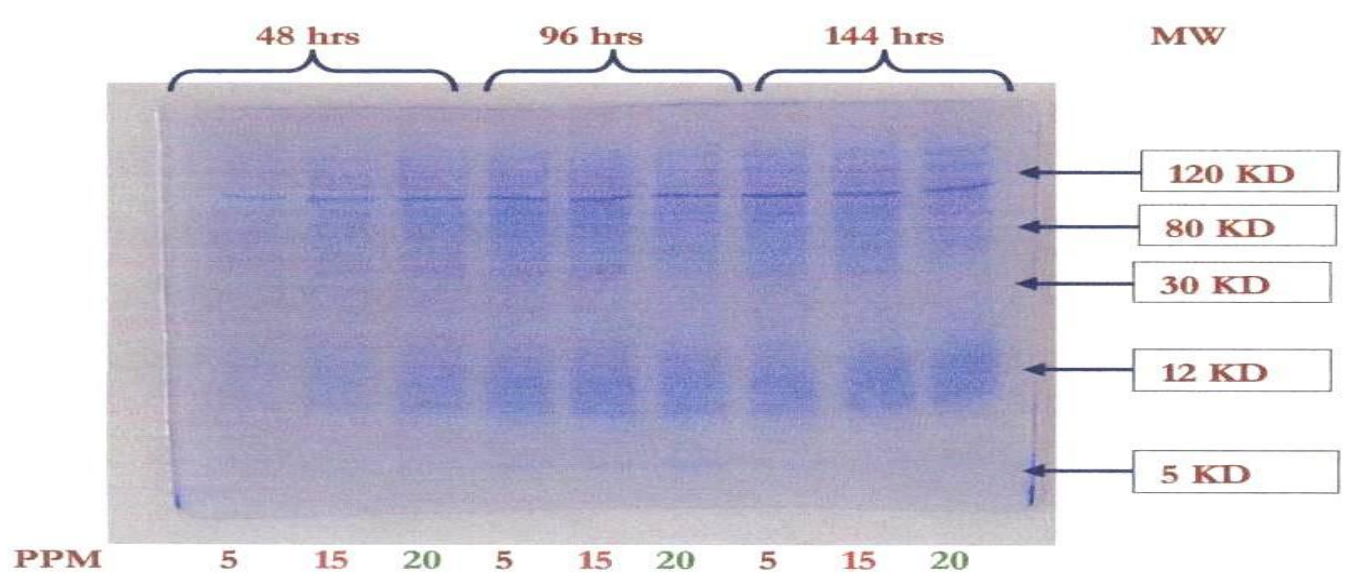


Fig: 1 The metallothionein expression in liver of $C$. carpio exposed to $\mathrm{As}_{2} \mathrm{O}_{3}$ at various concentrations (5 ppm, 15 ppm, and 20 ppm) at different time intervals (48 h, $96 \mathrm{~h}$, and $144 \mathrm{~h}$ ).

\section{Common Carp Kidney}

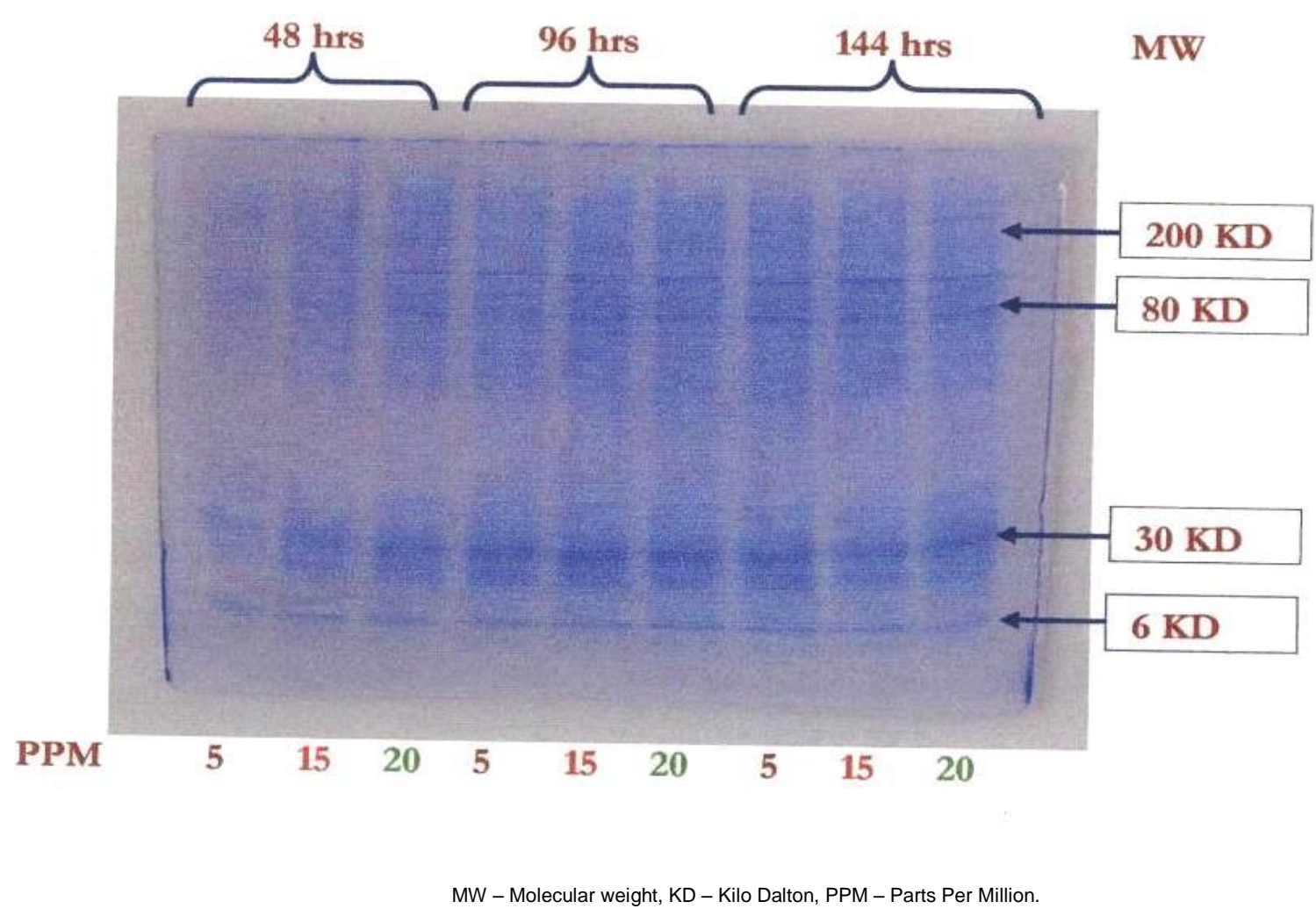

Fig: 2 The metallothionein expression in kidney of C. carpio exposed to $\mathrm{As}_{2} \mathrm{O}_{3}$ at various concentrations (5 ppm, 15 ppm, and $20 \mathrm{ppm})$ at different time intervals (48 h, $96 \mathrm{~h}$, and $144 \mathrm{~h})$.

\section{DISCUSSION}

Aquatic toxicity tests are used to evaluate the potential toxicological effects of environmental contaminants on aquatic biota (Rand and Petrocelli, 1985). It is necessary to study the presence of waterborne heavy metals on tolerance of the most sensitive bio-indicators of aquatic pollution, particularly fish (Gautam and Lall, 1989). In the present investigation, toxicity tests were conducted to evaluate the adverse effects of the heavy metal $\mathrm{As}_{2} \mathrm{O}_{3}$, on the freshwater fish $C$. carpio under standardized, reproducible conditions. Previous studies clearly shows that the acute exposure resulted in instantaneous death of fish because of As induced increases in mucus production, causing suffocation, or direct detrimental effects on gill epithelium. Similar behavioral activities were observed in the present study.

Most of the data on arsenic toxicity in fish are based on acute toxicity tests over $96 \mathrm{~h}$. Some studies have also examined sublethal effects on growth, avoidance behavior, and fertilization/hatching. According to these, there are many reports available on arsenic toxicity to freshwater fish. For instance, Lima et al. (1984) reported a significant effect of As reduced growth rate in fathead minnow (Pimephales 
promelas) to $4.3 \mathrm{mg} \mathrm{I}^{-1}$ and flag fish (Jordanella floridae) to $4.12 \mathrm{mg} \mathrm{I}^{-1}$. In addition, sodium arsenate altered significantly the hematological, biochemical parameters and liver transaminases activity in an Indian major carp, $C$. catla during acute treatment for $96 \mathrm{~h}\left(43.78 \mathrm{mg} \mathrm{l}^{-1}\right)$ and sublethal exposure for 35 days (4.378 $\mathrm{mg} \mathrm{l}^{-1}$ ) (Kavitha et al., 2010). In the present study, the 24, 46, 72, and $96 \mathrm{~h} \mathrm{LC}_{50}$ value of $\mathrm{As}_{2} \mathrm{O}_{3}$ to the fish C. carpio was found to be 25.2, $27.4,29.5$, and $32.0 \mathrm{mg} \mathrm{I}^{-1}$ respectively and $\mathrm{LC}_{16}$ and $\mathrm{LC}_{84}$ values were also observed (Table 1 ). In this study, an increase in exposure period was found drastically increased of $\mathrm{LC}_{50}$ values with increased level of concentrations of $\mathrm{As}_{2} \mathrm{O}_{3}$. Our results indicate that the observed $\mathrm{LC}_{50}$ value may be due to the sensitivity of the fish and purity of the compounds.

In the previous reports, the $\mathrm{LC}_{50}$ values of arsenate to the fish Carassius carrassius auratus and Oryzias latipes were found to be 10.00 and $30.3 \mathrm{mg} \mathrm{I}^{-1}$, respectively (Maeda et al., 1990; Suhendrayatna et al., 2002). On the other hand, arsenite was found to be $14.9 \mathrm{mg} \mathrm{I}^{-1}$ in Apelts quadricus and $16.0 \mathrm{mg} \mathrm{I}^{-1}$ in Menidia menidia (EPA, 1980); $15 \mathrm{mg} \mathrm{l}^{-1}$ in O. latipes (Suhendrayatna et al., 2002); $21.0 \mathrm{mg} \mathrm{I}^{-1}$ in Oncorhynchus mykiss (Wang et al., 2004); $8.4 \mathrm{mg} \mathrm{I}^{-1}$ in C. batrachus (Ghosh et al., 2006) and $18.211 \mathrm{mg} \mathrm{I}^{-}$ ${ }^{1}$ in Anabas testudineus (Akter et al., 2008). Further, $24 \mathrm{~h} \mathrm{LC}_{50}$ of arsenic trioxide to the fish larvae was found be $5 \mathrm{mg} \mathrm{l}^{-1}$ (Applegate et al., 1957) and $48 \mathrm{~h} 76$ $\mathrm{mg} \mathrm{I}^{-1}$ in Channa punctatus (Roy and Bhattacharya, 2005), $8.4 \mathrm{mg} \mathrm{l}^{-1}$ in Clarias batrachus (Ghosh et al., 2006) and $84 \mathrm{mg} \mathrm{I}^{-1}$ in C. batrachus (Bhattacharya and Bhattacharya, 2007). Likewise the $96 \mathrm{~h} \mathrm{LC}_{50}$ of sodium arsenate was $20.41 \mathrm{mg} \mathrm{l}^{-1}$ to Indian major carp C. catla (Kavitha et al., 2010) and arsenic trioxide to spine stickleback Apelts quadricus (14.9 $\mathrm{mg} \mathrm{I}^{-1}$ ); juvenile Atlantic silverside Menidia menidia (16.0 $\mathrm{mg} \mathrm{l}^{-1}$ ) (EPA, 1980); Labeo rohita (28.30 $\mathrm{mg} \mathrm{l}^{-1}$ ) (Vutukuru et al., 2007) and Indian major carp C. catla (43.78 $\mathrm{mg} \mathrm{I}^{-1}$ ) (Lavanya et al., 2011) were also observed in the previous studies. These reports clearly show that the toxicity of arsenicals is varying from one species to another and even in strains of the same species. Proteins are one of the most important and complete group of biological materials comprising of the nitrogenous constituents of the body and performing different biological functions. Metallothioneins (MTs) are a group of cytoplasmic proteins involved in metal regulation (Roesijadi, 1992). They belong to a class of low-molecularweight cysteine-rich metal-binding proteins found in a large number of prokaryotes and eukaryotes (Kagi and Kojima 1987). It is a small protein easily induced by heavy metals, hormones, and a variety of chemicals even at acute stress (Kagi 1993). In fish, MTs have been found in high concentrations in most of the vital organs such as liver, kidney, gill, and intestine (Roesijadi, 1992). In the present investigation, toxicity tests were conducted to evaluate adverse effects $\mathrm{As}_{2} \mathrm{O}_{3}$ on MT expressions using Sodium dodecyl sulphate- Polyacrylamide gel electrophoresis (SDS-PAGE) technique. The native and SDS-PAGE has been used as a valuable technique in the identification of the specific protein. The SDS-Page study revealed that the qualitative estimation of protein in fish. In the protein profile of the native PAGE, the control sample showed so many protein bands but the treated samples some protein bands were disappeared. Interestingly, low molecular proteins did not appear in the control sample but the treated sample showed low molecular proteins due to the induction of $\mathrm{As}_{2} \mathrm{O}_{3}$. In SDS-PAGE, the control sample did not showed any low molecular protein but the treated sample showed significantly increased concentration of the low molecular protein bands. It was also due to $\mathrm{As}_{2} \mathrm{O}_{3}$ stimulated synthesis of MT. So the above result clearly showed that the MT involved detoxification of $\mathrm{As}_{2} \mathrm{O}_{3}$ toxicity. MT induction has been proposed as one of the adaptive mechanisms for tolerance and a defense mechanism that protects the cell from the reactive intermediates to arsenic toxicity (Cherian, 1995).

Liver appeared to be the most sensitive organ for increased MT synthesis following exposure to a number of metals (Bhattacharya et al., 2007). In goldfish ( $C$. auratus) it has been proposed that hepatic MT protects the animal from metal xenobiotics by detoxication (Suzuki et al., 1987; Carpene et al., 1987). Such a way, the previous reports shows the induction of MT level in different organisms. For example, Huska et al. (2008) observed the increased MT content in cadmium exposure to Earthworm (Eisenia fetida) and significant induction of MT in the fish Seriola dumerilli (Jebali et al., 2006). Further, metals such as $\mathrm{Hg}$ and $\mathrm{Cd}$ those are also able to induce MT synthesis in both mammalian and piscine tissues (Sarkar 1997; Das et al., 1998; Roy 2003). Arsenicals are also effectively induced MT activity in mice (Kreppel et al., 1993a); rats (Albores et al., 1992) and fish (Roy and Bhattacharya, 2005). MT has been found at a very high concentration in the liver of mature animals after metal exposure (Chatterjee and Bhattacharya 1986). Kagi and Schaffer (1988) suggested that this property is due to its high cysteine content, which act as neutralizing 
nucleophilic equivalents. The most striking feature of MT is that it not only binds with heavy metals, but its synthesis is also induced by $\mathrm{Hg}, \mathrm{Cd}, \mathrm{Zn}$, and $\mathrm{As}$ (Agarwal and Bhattacharya 1990; Mukhopadhyay et al., 1994; Kuroshima 1995; Das et al., 1998). In this regard, Lee et al. (1992) found that the induction of MT genes and MT-like proteins in channel catfish liver followed by $\mathrm{Cd}$ and $\mathrm{Zn}$ exposure. Our results showed similar findings as in the previous reports. In the present study, the expression of MT was enhanced highly in the form of induced protein synthesis by $\mathrm{As}_{2} \mathrm{O}_{3}$. The level of liver As content among fish with maximal MT expression was similar to that of fish which similar to the previous literature on different forms of arsenicals. For example, Cd exposure induces MT in several tissues including liver and kidneys as shown in animals as well as in humans (Nordberg and Nordberg, 2000).

Similarly, Cui and Okayasu (2008) reported that the mRNA expression of MT-1 was enhanced by arsenic exposure in liver and it was decreased in kidney of rat even though there was no linear dose response and this result supports previous finding that arsenic exposure induces many stress proteins (Liu et al., 2001). The effect of As exposure on MT induction in kidney has not been measured more in freshwater fish. The results of the current study showed a significant induction of renal MT in response to dietary As exposure. A similar response was observed in the earlier studies on mammals (Albores et al., 1992). The MT induction may have occurred through activation of various antioxidant response elements located in the 5 promoting region of the MT gene, or alternatively, through the release of an unknown endogenous factors at an extra hepatic site (Schlenk et al., 1997).

\section{CONCLUSION}

The results of the present investigation indicate that $\mathrm{As}_{2} \mathrm{O}_{3}$ exposure during the acute treatments induced significant changes in the MT expression of common carp C. carpio. The presence of such levels of $\mathrm{As}_{2} \mathrm{O}_{3}$ in the natural environment will definitely affect the survival of fish and cause impacts to the human health. The results also imply a better understanding on the toxicological effects of this specific toxicant for ascertaining safe levels in the aquatic environment to protect the aquatic habitants. This parameter can be used as potential biomarker of arsenic toxicity to the freshwater fish in the field of environmental biomonitoring.

\section{ACKNOWLEDGMENTS}

The authors are thankful to Prof. T. Ambrose, Professor and Head, PG \& Research Department of Advanced Zoology and Biotechnology, Loyola College, Chennai for providing laboratory facilities and encouragement during the study period.

\section{REFERENCES}

Agarwal A and Bhattacharya, S (1990). Purification of a metallothionein-like protein (MLP) from the serum of $\mathrm{Hg}$ treated rats using phosphorylcholine-sepharose affinity column. Indian J. Exp. Biol. 28: 648-652

Akter, M.S., Ahmed, K., Akhand, A.A and Islam, M (2008). Acute toxicity of arsenic and mercury to fresh water climbing perch, Anabas testudineus (Bloch). World J. Zool. 3 (1): 13-18.

Albores, A., Koropatnick, J., Cherian, M.G and Zelazowski, A.J (1992). Arsenic induces and enhances rat hepatic metallothionein production in vivo. Chem. Biol. Interact. 85: 127-140.

Allen, T and Rana, S.V.S (2004). Effect of arsenic (AsIII) on glutathionedependent enzymes in liver and kidney of the freshwater fish Channapunctatus. Biol. Trace. El. Res. 100: 39-48.

Antman, K.H (2001). Introduction: The history of arsenic trioxide in cancer therapy. The Oncologist. 6: 1-2

APHA. (1980). American Public Health AssociationStandard Methods for the Examination of Water and Wastewater, 15th edition. APHA-AWWA-WPCF, Washington DC. $1000 \mathrm{p}$.

APHA, (1998). Standard Methods for the Examination of Water and Wastewater, 20th edition. American Public Health Association, Washington, DC.

Applegate, V.C., Howell, J.H., Hall, A.E and Smith, M.A (1957). Toxicity of 4, 346 chemicals to larval lampreys and fishes. Fish Wildl. Serv. Spec. Sci. Rep. 207: 157.

ATSDR, (2002). Interaction Profiles for Toxic Substances. Agency for Toxic Substances and Disease Registry. Atlanta, GA: Agency for Toxic Substances and Disease Registry, http://www.atsdr.cdc.gov/iphome.html.

ATSDR, (2006). Agency for Toxic Substances and Disease Registry, Toxicological Profiles for Arsenic. Atlanta, USA.

Bears, H., Richards, J.G and Schulte, P.M (2006). Arsenic exposure alters hepatic arsenic species composition and stress mediated-gene expression in the common Killifish (Fundulus heteroclitus). Aquat. Toxicol. 77: 257-266. 
Bernstam, L and Nriagu, J (2000). Molecular aspects of arsenic stress. J. Toxicol. Environ. Health B Crit. Rev. 3: 293-322.

Bhattacharya, A and Bhattacharya, S (2007). Induction of oxidative stress by arsenic in Clarias batrachus: involvement of peroxisomes. Ecotoxicol. Environ. Saf. 66: 178-187.

Bhattacharya, S., Bhattacharya, A and Roy, S (2007). Arsenic-induced responses in freshwater teleosts. Fish Physiol. Biochem. 33: 463-473.

Carpene, E., Cortesi, P., Tacconi, S., Cattami, O., Isane, G and Serrazanetti, G.P (1987). Cd-matallothionein and metal enzymes interaction in the goldfish. Carassius auratus. Comp. Biochem. Physiol. 86C: 267-272

Chakraborti, D., Mukherjee, S.C., Pati, S., Sengupta, M.K., Rahman, M.M., Chowdhury, U.K., Lodh, D., Chanda, C.R., Chakraborti, A.K and Basu, G.K (2003). Arsenic groundwater contamination in middle ganga plain, Bihar, India: a future danger ?. Environ. Health Perspect. 111: 1194-1197.

Chatterjee, A., Das, D and Chakraborti, D (1993). A study of ground water contamination by arsenic in the residential area of behala, Calcutta due to industrial pollution. Environ. Pollut. 80: 57-65.

Chaudhuri, S.D., Kundu, M., Banerjee, M., Das, J.K., Majumdar, P., Basu, S., Roychoudhury, S., Singh, K.V and Giri, A.K (2008). Arsenic-induced health effects and genetic damage in keratotic individuals: Involvement of p53 arginine variant and chromosomal aberrations in arsenic susceptibility. Mutation Res. 659: 118-125.

Cherian, M.G (1995). Metallothionein and its interaction with metals. Handb. Exp. Pharmacol. 115: 121-138

Cui, X and Okayasu, R (2008). Arsenic accumulation, elimination, and interaction with copper, zinc and manganese in liver and kidney of rats. Food Chem. Toxicol. 46 (12): 3646-3650.

Das, D., Chatterjee, A., Samanta, G., Mondal, B.K., Roy Chowdhury, T., Chowdhury, P.P. Chanda, C., Basu, G., Lodh, G and Nandi, S (1994). Arsenic contamination in groundwater in six districts of West Bengal, India: The biggest arsenic calamity in the world. Analyst. 119: 168-170.

Das, D., Sarkar, D and Bhattacharya, S (1998). Lipid peroxidative damage by arsenic intoxication is countered by glutathione-glutathione-S-transferase system and metallothionein in the liver of climbing perch, Anabas testudineus. Biomed. Environ. Sci. 11: 187-195.

Edmonds, J.S and Francesconi, K.A (1993). Arsenic in sea foods: human health aspect and regulations. Marine Pollut. 26: 665-674.
EPA, (1980). Ambient water quality criteria for lead. EPA Report, 440/5/80-057.

Finney, D.J (1942). The analysts of toxicity tests on mixtures of poisons. Ann. Appl. Biol. 29: 82-94.

Gautam, A.K and Lall, S.B (1989). Toxicity of zinc sulphate to Channa punctatus (BL). Proc. Symp. Environ. Toxicol, p 377-380.

Gernhöfer, M., Pawert, M., Schramm, M., Müller, E and Triebskorn, R. (2001). Ultra structural biomarkers as tools to characterize the health status of fish in contaminated streams. J. Aquat. Ecosyst. Stress Recover. 8: 241-260.

Ghosh, D., Bhattacharya, S and Mazumder, S (2006). Perturbations in the catfish immune responses by arsenic: organ and cell specific effects. Comp. Biochem. Physiol. C, Comp. Pharmacol. Toxicol. 143: 455-463.

Ghosh, D., Datta, S., Bhattacharya, S and Mazumder, S (2007). Long-term exposure to arsenic affects head kidney and impairs humoral immune responses of Clarias batrachus. Aquat. Toxicol. 81: 79-89.

Goering, L.P., Aposhian, V.H., Mass, J.M., Cebrian, M., Beck, D.B and Walkes, P.M (1999). The enigma of arsenic carcinogenesis: role of metabolism. Toxicol. Sci. 49: 5-14.

$\mathrm{He}, \mathrm{X}$ and $\mathrm{Ma}, \mathrm{Q}$ (2009). Induction of metallothionein I by arsenic via metal-activated transcription factor 1-critical role of $C$-terminal cysteine residues in arsenic sensing. J. Biol. Chem. 284 (19): 12609-12621.

Hughs, M.F (2002). Arsenic toxicity and potential mechanisms of action. Toxicol. Lett. 133: 1-16

Huska, D., Krizkova, S., Beklova, M., Havel, L., Zehnalek, J., Diopan, V., Adam, V., Zeman, L., Babula, P and Kizek, R (2008). Influence of cadmium (II) ions and brewery sludge on metallothionein level in earthworms (Eisenia fetida)-Bio-transforming of toxic wastes. Sensor, 8: 1039-1047.

IARC, (1987). Arsenic and Arsenic Compounds. In: IARC Monograph on the Evaluation of Carcinogenic Risks to Humans-Overall Evaluations of Carcinogenicity: An Update of IARC Monographs I to 42, IARC, Lyon, Suppl. 7, pp 100-103.

Jebali, J., Banni, M., Guerbej, H., Almeida, E.A. Bannaoui, $A$ and Boussett, $H$ (2006). Effects of malathion and cadmium on acetylcholinesterase activity and metallothionein levels in the fish Seriola dumerilli. Fish Physiol. Biochem. 32: 93-98.

Jin, Y., Sun, G., Li, X., Li, G., Lu, C and Qu, L (2004). Study on the toxic effects induced by different arsenicals in primary cultured rat astroglia. Toxicol. Appl. Pharmacol. 196: 396-403. 
Kagi, J.H.R (1993) Evolution, structure and chemical activity of class I metallothioneins: an overview. In: Suzuki, KT, Imura, N and Kimura, M (eds) Metallothionein III: biological roles and medical implications. Birkhauser Verlag, Berlin, pp 29-56

Kagi, J.H and Kojima, Y (1987). Chemistry and biochemistry of metallothionein. Exper. Suppl. 52: 2561.

Kagi, J.G.R and Schaffer, A. (1988). Biochemistry of Metallothionein. Biochemistry, 27: 8509-8515.

Kagi, J.H.R and Vallee, B.L (1960). Metallothionein: a cadmium- and zinc-containing protein from equine renal cortex. J. Biol. Chem. 235: 3460-3465.

Kang, Y.J (2006). Metallothionein redox cycle and function, Exp. Biol. Med. 231: 1459-1467.

Karim, M (2000). Arsenic in groundwater and health problems in Bangladesh. Wat. Resour. 34; 304-310.

Kavitha, C., Malarvizhi, A., Senthil Kumaran, S and Ramesh, M (2010). Toxicological effects of arsenate exposure on hematological, biochemical and liver transaminases activity in an Indian major carp, Catla catla. Food Chem. Toxicol. 48 (10): 2848-2854.

Kizek, R., Trnkova, L and Palecek, E (2001). Determination of metallothionein at the femtomole level by constant current stripping chronopotentiometry. Anal. Chem. 73: 4801-4807.

Kreppel, H., Bauman, J.W., Liu, J., McKim, J.M. Jr,, Klaassen, C.D (1993a). Induction of metallothionein by arsenicals in mice. Fundam. Appl. Toxicol. 20: 184189.

Krezel, A and Maret, W (2008). Thionein/metallothionein control $\mathrm{Zn}$ (II) availability and the activity of enzymes. J. Biol. Inorg. Chem. 13: 401-409.

Kuroshima, $\mathrm{R}$ (1995). Hepatic metallothionein and glutathione levels in red sea bream. Comp. Biochem. Physiol. 110C: 95-100

Laemmli, U.K (1970). Cleavage of structural proteins during the assembly of the head of bacteriophage T4. Nature. 227 (5259): 680-5.

Lavanya, S., Ramesh, M., Kavitha, C and Malarvizhi, A (2011). Hematological, biochemical and ionoregulatory responses of Indian major carp Catla catla during chronic sublethal exposure to inorganic arsenic. Chemosphere, 82 (7): 977-985.

Lee, S.Y., Lee, K.M., Suh, S.S., Song, Y.H and Lee, B.L (1992). Induction of metallothionein-proteins and metallothionein mRNA in channel catfish liver following cadmium and zinc treatment. Korean Biochem. J. 25 (1): 48-53.

Lima, A.R., Curtis, C., Hammermeister, D.E., Markee, T.P., Northcott, C.E and Brooke, L.T (1984). Acute and chronic toxicities of arsenic (III) to fathead minnows, flagfish, daphnids, and an amphipod. Arch. Environ. Contam. Toxicol. 13: 595-601

List, F.A (2002). New approaches to the treatment of myelodysplasia. Oncologist, 7: 39-49.

Liu, S.X., Athar, M., Lipai, I., Waldren, C and Hei, T.K (2001). Introduction of oxyradicals by arsenic, implication for mechanism of genotoxicity. Proc. Nat. Acad. Sci. USA, 98: 1643-1648.

Maeda, S., Inoue, R., Kozono, T., Tokuda, T., Ohki, A and Takeshita, T (1990). Arsenic metabolism in a freshwater food chain. Chemosphere, 20: 101.

Maret, W (2008). Metallothionein redox biology in the cytoprotective and cytotoxic functions of zinc, Exp. Gerontol. 43: 363-369.

Mukhopadhyay, B., Bose, S and Bhattacharya, S (1994). Induction of metallothionein in rat liver by cadmium chloride: probable mechanism of action. Biomed. Environ. Sci. 1: 232-240

Nordberg, M and Nordberg, G.F (2000). Toxicological aspects of metallothionein. Cell. Mol. Biol. 46: 451-463.

Nordstrom, D.K (2002). Public health. Worldwide occurrences of arsenic in ground water. Science, 296: 2143-2145.

NRC, (1999). Arsenic in Drinking Water. National Research Council, Washington, DC.

Pacyna, J.M., Scholtz, M.T and Li, Y.F (1995). Global budgets of trace metal sources. Environ. Rev. 3: 145159.

Palaniappan, P.L.R.M and Vijayasundaram, V (2008). Fourier transform infrared study of protein secondary structural changes in the muscle of Labeo rohita due to arsenic intoxication. Food Chem. Toxicol. 46: 35343539.

Palaniappan, P.L.R.M and Vijayasundaram, V (2009). The effect of arsenic exposure and the efficacy of DMSA on the proteins and lipids of the gill tissues of Labeo rohita. Food Chem. Toxicol. 47: 1752-1759.

Pedlar, R.M., Ptashynski, M.D., Evans, R and Klaverkamp, J.F (2002). Aquat. Toxicol. 57: 167-189.

Phillips, D.J.H (1990). Arsenic in aquatic organisms, a review, emphasizing chemical speciation. Aquat. Toxicol. 16: 151-186.

Rand, G and Petrocelli, S.R (1985). Fundamentals of aquatic toxicology, methods and applications, Hemsiphere, New York, pp 1-28.

Ratnaike, R.N (2006). Acute and chronic arsenic toxicity. Postgad. Med. J. 79: 391-396.

Robinson, N.J. Gupta, A., Fordham-Skelton, A.P., Croy, R.R.D., Whitton, B.A and Huckle, J.W (1990). 
Prokaryotic metallothionein gene characterization and expression: chromosome crawling by ligation-mediated PCR. Proc. R. Soc. Lond. B. 242: 241-247.

Rodrıguez, V.M., Jimenez-Capdeville, M.E and Giordano, $M$ (2003). The effects of arsenic exposure on the nervous system. Toxicol. Lett. 145: 1-18.

Roesijadi, G (1992). Metallothionein in metal regulation and toxicity in aquatic animals. Aquat. Toxicol. 22: 81-114.

Roy, S (2003). Interactive mechanism of intoxication and detoxication in Clarias batrachus hepatocytes exposed to cadmium and lead. Ph. D. Dissertation, Visva Bharati University, Santiniketan, India.

Roy, S and Bhattacharya, S (2005). Arsenic-induced histopathology and synthesis of stress proteins in liver and kidney of Channa punctatus. Ecotoxicol. Environ. Saf. 65: 218-229.

Sarkar, D (1997). Role of reduced glutathione, glutathioneStransferase, metallothonein and lipid peroxidation in the detoxication mechanism in Anabas testudineus (Bloch). Ph. D. Dissertation, Visva Bharati University, Santiniketan, India.

Saxena, P.N., Anand, S., Saxena, N and Bajaj, P (2009). Effect of arsenic trioxide on renal functions and its modulation by Curcuma aromatica leaf extract in albino rat . J. Environ. Biology. 30 (4): 527-531.

Schlenk, D., Wolford, L., Chelius, M., Steevens, J and Chan, K.M (1997). Effect of arsenite, arsenate, and the herbicide monosodium methyl arsonate (MSMA) on hepatic metallothionein expression and lipid peroxidation in channel catfish. Comp. Biochem. Physiol. 118 (2): 177-183.

Stillman, M.J., Shaw III, C.F and Suzuki, K.T (1992). Metallothioneins, in: M.J. Stillman, C.F. ShawlII, K.T. Suzuki (Eds.), Metallothioneins: Synthesis, Structure and Properties of Metallothioneins, Phytochelatins and Metal-Thiolate Complexes, VCH Publishers, New York, pp 1-12.
Sturzenbaum, S.R., Kille, P and Morgan, A.J (1998). The identification, cloning and characterization of earthworm metallothionein. FEBS Lett. 431: 437-442.

Suhendrayatna, Ohki, A., Nakajima, T and Maeda, S (2002a). Chemosphere, 46 (2): 319-324.

Suzuki, K.T., Sunaga, H., Kotayashi, E and Hatekeyama, $S$ (1987). Environmental and injected cadmium are sequestered by two major isoforms of basal copper, zinc-metallothionein in gibel (Carassius auratus langsdorfi) liver. Comp. Biochem. Physiol. 87C: 87-94.

Trnkova, L., Kizek, R and Vacek, J (2002). Catalytic signal of rabbit liver metallothionein on a mercury electrode: a combination of derivative chronopotentiometry with adsorptive transfer stripping. Bioelectrochemistry, 56: 57-61.

Vahter, M (1994). Species difference in the metabolism of arsenic compounds. Appl. Organomet. Chem. 8: 175.

Vutukuru, S.S (2003). Chromium induced alterations in some biochemical profiles of the Indian major carp, Labeo rohita (Hamilton). Bull. Environ. Contam. Toxicol. 70: 118-123.

Vutukuru, S.S., Prabhath, N.A., Raghavender, $M$ and Yerramilli, A (2007). Effect of Arsenic and chromium on the serum amino-transferases activity in Indian major carp, Labeo rohita. Int. J. Environ. Res. Public Health. 4 (3): 224-227.

Wakao, N., Koyatsu, H and Komai, Y (1988). Microbial oxidation of arsenite and occurrence of arseniteoxidizing bacteria in acid mine water from a sulfurpyrite mine. Geomicrobiol. J. 6: 11-24.

Wang, Y.C., Chaung, R.H and Tung, L.C (2004). Comparison of the cytotoxicity induced by different exposure to sodium arsenite in two fish cell lines. Aquat. Toxicol. 69: 67-79.

Wrobel, K., Wrobel, K., Parker, B., Kannamkumarath, S.S and Caruso, J.A (2002). Determination of As (III), As (V), monomethylarsonic acid, dimethylarsinic acid and arsenobetaine by HPLC-ICP-MS: analysis of reference materials, fish tissues and urine. Talanta, 58: 899-907. 